\title{
LOS EFECTOS TEMPORALES DE LA ANULACIÓN POR ANULABILIDAD EN ITALIA, FRANCIA Y ALEMANIA (CONFLUENCIAS CON EL DERECHO ESPAÑOL)
}

\author{
JOSÉ ANTONIO TARDÍO PATO \\ Universidad Miguel Hernández de Elche \\ i.a.tardio@umh.es
}

\author{
Cómo citar/Citation \\ Tardío Pato, J. A. (2018). \\ Los efectos temporales de la anulación por anulabilidad en \\ Italia, Francia y Alemania (confluencias con el derecho español). \\ Revista de Administración Pública, 206, 357-385 \\ doi: https://doi.org/10.18042/cepc/rap.206.12
}

\section{Resumen}

Versa sobre el tratamiento de los efectos de la anulación de los actos administrativos anulables en Italia, Francia y Alemania y su comparación con las soluciones formuladas por la doctrina científica y la jurisprudencia españolas. Las conclusiones muestran coincidencias finales entre los cuatro derechos, a pesar de las distintas trayectorias seguidas en algunos de ellos.

\section{Palabras clave}

Anulabilidad; efectos ex nunc; efectos ex tunc; invalidez de los actos administrativos.

\section{Abstract}

It deals with the treatment of the annulment effects of voidable administrative acts in Italy, France and Germany and their comparison with the solutions formulated by Spanish scientific doctrine and case law. The conclusions show final coincidences among the four Laws, despite the different trajectories followed in some of them.

\section{Keywords}

Voidable; ex nunc effects; ex tunc effects; invadility of administrative acts. 


\section{SUMARIO}

I. INTRODUCCIÓN. II. SU REGULACIÓN EN EL DERECHO FRANCÉS. III. SU TRATAMIENTO EN EL DERECHO ITALIANO. IV. LAS PREVISIONES DEL DERECHO ALEMÁN. V. CONCLUSIONES: COINCIDENCIAS FINALES A PESAR DE LAS DIFERENTES TRAYECTORIAS.

\section{INTRODUCCIÓN}

En mis anteriores análisis sobre los efectos de la anulabilidad de los actos administrativos en el derecho español, creo haber acreditado, con la referencia precisa a las correspondientes sentencias de nuestro Tribunal Supremo, que la afirmación doctrinal y de algunas sentencias de la existencia de una correlación entre efectos ex tunc de la nulidad de pleno derecho y efectos ex nunc de la nulidad no es correcta ${ }^{1}$ y que la aseveración de los efectos necesariamente

1 J. A. Tardío Pato (2017), «El mito de los efectos ex nunc de la anulación por anulabilidad», en F. López Ramón y F. Villar Rojas (coords.), El alcance de la invalidez de la actuación administrativa, Actas del XII Congreso de la Asociación Nacional de Profesores de Derecho Administrativo, La Laguna 3 y 4 de febrero de 2017, Madrid: Instituto Nacional de Administración Pública (págs. 195 y ss); (2017), «Los efectos ex tunc de la anulabilidad», Civitas, Revista Española de Derecho Administrativo, 184, págs. 75-107; antes también en (2011), Lecciones de Derecho Administrativo. Acto administrativo, procedimiento y recursos administrativos y contencioso-administrativos, San Vicente del Raspeig (Alicante): ECU (págs. 48-51).

Igualmente se encuentra destacado en otros autores españoles (algunos de los cuales he citado ya en los referidos trabajos): M. Beladíez Rojo (1994), «La nulidad y la anulabilidad. Su alcance y significación", Revista de Administración Pública, 133 (pág. 167); T. Cano Campos (2004), La invalidez sobrevenida de los actos administrativos, Madrid: Ed. Thomson-Civitas (págs. 217 y ss); (2017), «Validez e invalidez de los actos administrativos: teoría general», en E. Gamero Casado, S. Fernández Ramos y J. Valero Torrijos (coords.), Tratado de Procedimiento Administrativo Común y Régimen Jurídico Básico del Sector Público, vol. II, Valencia: Tirant Lo Blanch (pág. 1916); (2017), «El laberinto de la invalidez: algunas pistas para no perderse», en F. López Ramón y F. Villar Rojas (coords.), El alcance de la invalidez de la actuación admi- 
ex nunc de la anulabilidad en derecho privado y en derecho público constituye un auténtico mito no coincidente con la realidad ${ }^{2}$.

Así, la mayor parte de la doctrina científica del derecho privado en Espańa ha venido defendiendo que la sentencia de declaración de anulabilidad, aunque pueda considerarse declarativa y no constitutiva (a diferencia de la sentencia de declaración de nulidad de pleno derecho, que sí tendría este último carácter), una vez producida, sin embargo, tiene eficacia retroactiva, o sea $e x$ tunc $^{3}$.

nistrativa, Actas del XII Congreso de la Asociación Nacional de Profesores de Derecho Administrativo, La Laguna, 3 y 4 de febrero de 2017, Madrid: Instituto Nacional de Administración Pública (págs. 82-84); V.S. Baca Oneto (2006), La invalidez de los contratos públicos, Cizur Menor (Navarra): Ed. Thomson-Civitas (págs. 344-346); M. Rebollo Puig (2009), «La nulidad en Derecho Administrativo (consideración de su significado y régimen en el actual Derecho Administrativo español, a propósito de la nulidad y los derechos fundamentales)», Justicia Administrativa, 44 (pág. 13); (2017), «La invalidez del acto administrativo», en M. Rebollo Puig y D. Vera Jurado (dirs.), Derecho Administrativo, vol. II, 2a edición, Madrid: Tecnos (págs. 110-112); S. Muñoz Machado (2015), Actos administrativos y sanciones administrativas, tomo XII del Tratado de Derecho Administrativo y Derecho Público General, Madrid: BOE (pág. 186); y M. R. Alonso Ibáńez (2017), «Régimen general de invalidez de los actos administrativos y sus efectos», en F. López Ramón y F. Villar Rojas (coords.), El alcance de la invalidez de la actuación administrativa, Actas del XII Congreso de la Asociación Nacional de Profesores de Derecho Administrativo, La Laguna, 3 y 4 de febrero de 2017, Madrid: Instituto Nacional de Administración Pública (pág. 32).

2 Que era un mito ya lo habían resaltado J. A. Santamaría Pastor (1972), La nulidad de pleno derecho de los actos administrativos, Madrid: Instituto de Estudios Administrativos (págs. 184 y ss.); J. A. García Trevijano Fos (1991), Los actos administrativos, 2a edición, Madrid: Civitas (pág. 398); R. Gómez-Ferrer Morant (1993), «La revisión de oficio», en J. Leguina Villa y M. Sánchez Morón (coords.), La nueva Ley de Régimen jurídico de las Administraciones públicas y del procedimiento común, Madrid: Tecnos (pág. 300); A. Nieto García (1994), «Estudio Preliminar» al libro de M. Beladíez Rojo, Validez y eficacia de los actos administrativos, Madrid: Marcial Pons (pág. 17); M. Beladíez Rojo (1994), Validez y eficacia de los actos administrativos, Madrid: Ed. Marcial Pons (pág. 63); M. Beladíez Rojo (1994: 161 y 167); y E. García-Trevijano Garnica (1996), «Consideraciones sobre la revocación de los actos administrativos no declarativos de derechos y de gravamen", Civitas, Revista Española de Derecho Administrativo, 91 (pág. 436), entre otros.

Sin embargo, J. Jordano Fraga (1997), Nulidad de los actos administrativos y derechos fundamentales, Madrid: Marcial Pons (págs. 178 y ss.), siguió defendiendo los efectos ex nunc de la anulabilidad.

3 J. A. Tardío Pato (2017: epígrafe II, letra A). En dicho lugar, de la doctrina científica civil, cito a F. de Castro y Bravo (1971), El negocio jurídico, Madrid: Instituto Nacio- 
Y esto mismo podía afirmarse tanto de la jurisprudencia civil en sentido propio $^{4}$ como de la denominada jurisprudencia menor de dicho orden jurisdiccionals.

En cuanto al derecho administrativo, en la doctrina científica, aunque en un primer momento fueron defendidos por algunos autores los efectos ex nunc, más adelante se sostuvo que era un error y que el criterio general era el

nal de Estudios Jurídicos (págs. 479 y 508); L. Díez-Picazo y A. Gullón Ballesteros (2003), Sistema de Derecho Civil, vol. I, 11 ed., Madrid: Tecnos SA. (pág. 550); A. Gullón Ballesteros (1960), «La confirmación», Anuario de Derecho Civil, año 1960, fasc. 4 (pág. 1218); L. Díez-Picazo (1961), «Eficacia e ineficacia del negocio jurídico», Anuario de Derecho Civil, año 1961, fasc. 4 (pág. 826); (1993), «La anulabilidad de los contratos», en Estudios de Derecho Civil en homenaje al profesor José Luis Lacruz Berdejo, vol. II, Barcelona: Bosch (págs. 1228-1229; (1996), Fundamentos del Derecho Civil patrimonial. Vol. I. Introducción. Teoría del contrato, $5^{\text {a }}$ edición, Madrid: Civitas (pág. 495); M. Albaladejo (2004), Derecho Civil I. Introducción y parte general, 16a ed., Madrid: Edisofer (págs. 868-869 y 872); J. Delgado Echevarría (1991), «Comentario al art. 1300 del CC.», en J. Delgado Echevarría, C. Paz-Ares Rodríguez, R. Bercovitz y P. Salvador Coderch (coords.), Comentario del Código Civil, vol. II, Madrid: Secretaría General Técnica-Centro de Publicaciones del Ministerio de Justicia (pág. 543); J. L. de los Mozos (1987), «La nulidad de los actos jurídicos», en El negocio jurídico (estudios de Derecho Civil), Madrid: Montecorvo (pág. 601); C. López Beltrán de Heredia (2009), La nulidad de los contratos, Valencia: Tirant lo Blanch (pág. 43); M. Pasquau Liaño (1997), Nulidad y anulabilidad del contrato, Madrid: Civitas (pág. 176); A. Colás Escandón (2001), "Comentario al art. 1300 del CC», en R. Bercovitz Rodríguez-Cano (coord.), Comentarios al Código Civil, Cizur Menor: Ed. Aranzadi (pág. 1522).

4 Así en la STS de 27 de noviembre de 1998 (RJ 1998\9324, FJ. 1) y en la STS de 26 de enero de 1999 (RJ 1999\322). Como también, en la STS 241/2013, de 9 de mayo (RJ 2013\3088), sobre la anulación de las cláusulas suelo en las hipotecas, aunque en esta sentencia, después de invocar otros argumentos adicionales a favor de la retroactividad de dicha declaración al momento de la conclusión del contrato, se decantó por la irretroactividad de la declaración de nulidad, esgrimiendo principios generales del derecho como el de seguridad jurídica o el de enriquecimiento sin causa y determinados preceptos vinculados a los mismos.

No obstante, la STJUE de 21 de diciembre de 2016 (Gran Sala, asuntos acumulados C154/15, C307/15 y C308/15), sobre esa misma materia de las cláusulas suelo, declaró que la Directiva europea aplicable exigía la retroactividad de la anulación de las cláusulas abusivas y no admitía sentencias que limitasen tal retroactividad.

5 Puede comprobarse en la SAP de Madrid (Sección 21a), núm. 405/2016, de 18 octubre (JUR 2016 276503) sobre la suscripción de participaciones preferentes y demás que cito de la misma Sala y de las Salas de Ávila, Valencia y Castellón, sobre la misma cuestión. Véase J. A.Tardío Pato (2017: 197; 2017: epígrafe II, letra C). 
opuesto. Y, en la actualidad, puede afirmarse que la postura predominante es la que defiende que la anulación por vicios de anulabilidad genera como regla general efectos ex tunc, sin perjuicio de que caben excepciones por la incidencia de determinados principios generales del derecho ${ }^{6}$.

La jurisprudencia del Tribunal Constitucional puede resumirse en los siguientes términos: para que los efectos en la anulabilidad sean ex tunc, ha de recogerse ya en la sentencia declarativa, puesto que, si no se hace, ya no se podrán imponer judicialmente en fase de ejecución de sentencia, sin lesionar la intangibilidad de las sentencias y el derecho a la tutela judicial efectiva de la parte afectada ${ }^{7}$. Por el contrario, sí que se admite que la resolución judicial ejecutiva en estos casos imponga efectos ex nunc, sin que ello resulte irrazonable, incongruente, arbitrario o erróneo ${ }^{8}$. Pero en ningún momento se afirma que la anulabilidad conduzca necesariamente a los efectos ex nunc, pues se admite que se establezcan efectos ex tunc en la sentencia declarativa?.

En la jurisprudencia del Tribunal Supremo no hay unanimidad de criterio. Hay, así, sentencias del Tribunal Supremo que han declarado los efectos ex nunc como un dogma, sin argumentos justificativos de ello, en asuntos no configurados por una normativa específica y, sobre todo, han recogido tales efectos las sentencias tributarias que defienden el efecto interruptivo de la prescripción de las liquidaciones anuladas por falta de motivación. Si bien algunas de ellas incluyen votos particulares con relevantes razonamientos en favor de los efectos ex tunc ${ }^{10}$.

Pero también existen sentencias del Tribunal Supremo que declaran la procedencia de efectos ex tunc. Entre ellas, podemos encontrarlas de las no determinadas por una regulación sectorial concreta; otras producidas en el ámbito de la recaudación de cuotas de la Seguridad Social; otras en el sector de adjudicaciones de plazas de funcionario con reconocimiento del mejor derecho del recurrente y efectos de antigüedad y económicos correlativos; otras de anulación de resoluciones de no ampliación del servicio activo más allá de los 65 ańos, y, finalmente, otras de anulación de sanciones que conllevan el cese en el ejercicio de las funciones ${ }^{11}$.

6 Me remito a las citas realizadas en J. A.Tardío Pato (2017: 197-198; 2017: epígrafe III) y en la nota 1 del presente trabajo.

7 STC 106/1999 (FJ 60).

8 STC $83 / 2001$.

9 Para el detalle completo del razonamiento de dichas sentencias, me remito a J. A. Tardío Pato (2017: epígrafe IV).

10 El detalle de tales sentencias y de los referidos votos particulares en J. A. Tardío Pato (2017: epígrafe V).

11 Para la referencia exacta de tales sentencias me remito a J. A. Tardío Pato (2017: epígrafe VI). 
En cualquier caso, en alguna de las resoluciones judiciales que defienden los efectos ex tunc como regla general, han sido invocados, para modular las consecuencias de ello, no solo el principio de confianza legítima ${ }^{12}$, sino también otros principios jurídicos, como los de buena fe, proporcionalidad, enriquecimiento sin causa u otros tantos que pudieran ser aplicables al supuesto específico ${ }^{13}$.

12 STS de 28/7/1986 (RJ 1986l6902), FJ 3º. Y, en la doctrina científica, R. Bocanegra Sierra (2002), Lecciones sobre el acto administrativo, Madrid: Civitas (pág. 191); (2005), La teoría del acto administrativo. Madrid: Iustel (pág. 199); y J. García Luengo (2002), La nulidad de pleno derecho de los actos administrativos, Madrid: Civitas (pág.s 305 y ss.); (2002), El principio de protección de la confianza legitima, Madrid: Civitas (págs. 412 y ss.).

Respecto a las distintas consecuencias jurídicas del principio de confianza legítima en Espańa, las recojo en mi trabajo, que analiza la incidencia de tal principio en la problemática de la retroactividad de la jurisprudencia: J. A. Tardío Pato (2017), «La retroactividad de la jurisprudencia como peligro para la seguridad jurídica y la confianza legítima», CEF Legal. Revista Práctica de Derecho, 203 (págs. 139-140). Son las siguientes:

a) La anulación de la norma que incorpora el cambio, incluso si tiene rango de ley (SSTC 173/1996, FJ 5. ${ }^{\circ}$, y 89/2009, FFJ $5 .^{\circ}$ y 6. ${ }^{\circ}$ ), o del acto que acoge un nuevo criterio aplicativo (STS de 22/1/2013, RJ 2013\2367, FJ 7º, y la STS 4/11/2013, RJ 2013।7219, FJ 20);

b) La conservación de actos que, de no mediar la confianza legítima, deberían desaparecer (STS de 8/5/2013, RJ 201315038, FJ 3, penúltimo párrafo);

c) El reconocimiento de una indemnización (STS de 30/6/2001, RJ 2001/8220, FJ 8º respecto de una Ley de 1991 del Parlamento Balear); y

d) Otros modos de compensación, como no entender incumplido el plazo de interposición del recurso que no interpuso en su momento por haber sido inducido el ciudadano por la Administración a utilizar una vía impugnatoria inadecuada (STS de 18/6/2013, RJ 201315999, que invoca las anteriores SSTS de 13/7/2012, RJ 201218172; 16/2/2012, RJ 2012\4080); que no pueda oponerse a la adquisición por el apelado de un derecho a edificar (STS de 20 de enero de 1998, RJ19981243, FJ 5.); o que no se considere anulada la autorización para que pueda edificarse en la zona de servidumbre de aeropuerto (STS de 20 de enero de 2014, RJ 2014l632, y las que ella cita).

13 En los anteriores trabajos citados, invoco como ejemplo el caso de reconocimiento de efectos económicos de la anulación de una adjudicación de una plaza funcionarial, con reconocimiento del mejor derecho del recurrente que recoge la jurisprudencia del TS, en la aplicación del principio de enriquecimiento sin causa para excluir el pago de aquellas cantidades coincidentes con otras percibidas por el recurrente en el mismo período. 


\section{SU REGULACIÓN EN EL DERECHO FRANCÉS}

En Francia, nuestros actos nulos de pleno derecho, los que incurren en los vicios más graves, se califican como actos inexistentes (actes inexistants) ${ }^{14}$, en el sentido de inexistencia jurídica (no mera inexistencia material, por no haberse producido en la realidad) ${ }^{15}$ y son considerados como no productores de efecto alguno (la terminología jurisprudencial habitual es nul et non ave$n u$ ), o sea que su anulación (a través del recurso de declaración de inexistencia o incluso a través del recurso por exceso de poder ${ }^{16}$ ) conlleva efectos ex tunc ${ }^{17}$.

En el caso de nuestros actos anulables, se habla de actos incursos en ilegalidad ordinaria (illégalité ordinaire), también llamada ilegalidad normal (illégalité normale) ${ }^{18}$ y de "simple nulidad» (simple nullité) ${ }^{19}$. Su instrumento de impugnación ordinario es el recurso por exceso de poder ante el órgano jurisdiccional administrativo ${ }^{20}$ y la regla general es la de la anulación del acto declarado ilegal con efectos retroactivos, o sea con efectos ex tunc $c^{21}$.

Como también evoco el ejemplo real que recojo en mi libro sobre los principios generales del derecho: J. A.Tardío Pato (2011), Los Principios Generales del Derecho. Su aplicación efectiva como normas jurídicas, Barcelona: Bosch (págs. 235 y ss). Se trata de la anulación de un nombramiento como profesor titular de universidad interino a un candidato que no tenía homologado en Espańa el título de doctor obtenido en una universidad extranjera (además por nulidad de pleno derecho, mediante revisión de oficio de actos nulos, con dictamen favorable del Consejo Jurídico Consultivo de la Comunidad Valenciana 188/1997, de 8 de octubre, expediente 1997/222), en el que se respetan las retribuciones percibidas por el mismo, por aplicación del principio de enriquecimiento sin causa. Pero en el que también se respetan las calificaciones académicas otorgadas, por garantía del principio de confianza legítima de los alumnos y del principio de continuidad de los servicios públicos.

14 Aquí se incluyen los supuestos de vía de hecho y otros recogidos en la jurisprudencia, relacionados en las obras doctrinales. Así R. Chapus (2001), Droit Administratif Genéral, t. I, 15 ed., Paris: Editions Montchrestien E.J.A. (págs. 1014-1015); G. Braibant y B. Stirn (2005), Le Droit Administratif Français. 7e édition, Paris: Presses de Sciences PO et Dalloz (págs. 310-312).

15 G. Braibant y B. Stirn (2005: 309).

16 R. Chapus (2001: 790).

17 Ibid.: 1014.

18 G. Braibant y B. Stirn (2005: 302).

19 Y. Gaudemet (2015), Droit Administratif, 21 édition, Paris: LGDJ (pág. 133).

20 G. Braibant y B. Stirn (2005: 304); R. Chapus (2001: 786-787 y 1013); J. Waline (2016), Droit Administratif, 26 ed., Paris: Ed. Dalloz (pág. 705).

21 R. Chapus (2001: 786-787 y 1013); J. Waline (2016: 705); G. Braibant y B. Stirn (2005: 302 y ss., en especial, pág. 306); e Y. Gaudemet (2015:162). 
Y, aunque se habían destacado supuestos problemáticos sobre dichos efectos $^{22}$, ha sido especialmente a partir de la décision del Consejo de Estado de 11 de mayo de $2004^{23}$ que se ha empezado a destacar la posibilidad de modulación de dicha regla general, incluyendo otros efectos temporales de la anulación.

Declara exactamente el alto órgano jurisdiccional contencioso-administrativo francés que:

[...] la anulación de un acto administrativo implica, en principio, que este acto se considera que nunca se ha producido. Sin embargo, si se considera que el efecto retroactivo de la cancelación es probable que implique consecuencias manifiestamente excesivas, tanto por los efectos que este acto ha producido y por las situaciones que han podido ser constituidas cuando estaba en vigor, como por el interés general que puede atribuirse a un mantenimiento temporal de sus efectos, corresponde al juez administrativo [...] tomar en consideración, por una parte, las consecuencias de la retroactividad de la anulación para los diversos intereses públicos o privados en presencia y, por otra, los inconvenientes que presentaría, desde el prisma del principio de legalidad y del derecho de los justiciables a una tutela efectiva, una limitación temporal de los efectos de la anulación.

A lo que añade que corresponde a dicho juez:

[...] apreciar, en lo atinente a estos elementos, si los mismos pueden justificar la inaplicación a título excepcional del principio del efecto retroactivo de las anulaciones contenciosas y, en caso afirmativo, de prever en su decisión de anulación que [...], todos o parte de los efectos de este acto anteriores a su anulación deberán ser contemplados como definitivos o incluso, si fuera el caso, que la anulación no tendrá efecto más que en una fecha posterior que él determine.

Y esta sigue siendo la doctrina jurisprudencial que puede encontrarse en las décisions del Consejo de Estado más recientes ${ }^{24}$.

22 J. Waline menciona supuestos de colisión con el principio de seguridad jurídica y con la confianza de los administrados (2016: 705-706).

23 C.E., 11 mai 2004, Association AC! et autres, G.A., no 118. Conseil d'État nº 255886, ECLI:FR:CEASS:2004:255886.20040511. Publié au recueil Lebon.

24 Así las Décisions de 28 de septiembre de 2016 (Formation professionnelle dans le notariat, Conseil d'État no 377190, ECLI:FR:CECHR:2016:377190.20160928. Mentionné aux tables du recueil Lebon; parágrafo 7); 20 de marzo de 2017 (Association de défense des agriculteurs de La Réunion, Conseil d'État n 395326, EC LI:FR:CECHR:2017:395326.20170320. Mentionné aux tables du recueil Lebon; 
G. Braibant y B. Stirn ponen dos ejemplos de la regla general y de la justificación de la excepción a dicha regla. Invocan como un caso paradigmático de anulación con efectos ex tunc el de la anulación de la remoción o cese de un funcionario y como paradigma de justificación de excepción a la regla general el de la anulación de un procedimiento de acceso a una Escuela Superior (de las denominadas Grandes Écoles).

En el primer caso, indican que será necesario reintegrar al funcionario; reconstituir su carrera por el período en que ha sido depuesto; pagarle los aumentos que no ha recibido y otorgarle, por último, una indemnización en compensación por los demás factores. Pero, en el segundo caso, añaden que hay que reconocer que objetivamente es difícil de llevar hasta sus últimas consecuencias la aplicación completa del principio del efecto retroactivo de la anulación ${ }^{25}$.

Otros autores destacan supuestos en los que la regla general debe excepcionarse en interés de la seguridad jurídica de los administrados o de razones de imposibilidad material, jurídica o práctica ${ }^{26}$.

Como ejemplo de razón material, se pone el de la anulación de la resolución que prohibió una reunión, mucho tiempo después de la fecha prevista para su realización.

Como ejemplo de razón jurídica, los supuestos en los que ha recaído el efecto de cosa juzgada.

Y, como ejemplo de razón práctica, el de situaciones generadas por actos de un funcionario cuyo nombramiento es posteriormente anulado ${ }^{27}$.

Una de las últimas manifestaciones en la jurisprudencia del Consejo de Estado de las modulaciones a los efectos ex tunc automáticos, donde pueden observarse claramente en qué consisten tales modulaciones, lo encontramos en la reciente Décision del Consejo de Estado de 9 de marzo de 2018, que anula el Acuerdo de la Comisión Reguladora de la Energía de 2016 sobre las tarifas de uso de las redes eléctricas públicas de alta (HTA) y baja (BT) tensión, aplicable a partir de determinada fecha. En dicha décision se destaca que la anulación obligaría al operador de red a enviar a todos los usuarios de la red pública de distribución de electricidad, que pagan las tarifas de usuario, facturas correctivas. Y se declara que tales circunstancias «justifican que el juez

parágrafo 9); y de 9 de marzo de 2018 (Délibération de la Commission de régulation de l'énergie du 17 novembre 2016 arrêtant les tarifs d'utilisation des réseaux publics d'électricité de tension HTA et BT, Conseil d'État n 407516, ECLI:FR:CEC HR:2018:407516.20180309).

25 G. Braibant y B. Stirn (2005: 306-307).

26 J. Waline (2016: 705).

27 Ibid. 
haga uso de su poder de modulación a lo largo del tiempo sobre los efectos de esta anulación" y, por ello, prever que los efectos producidos por el acto impugnado se consideren firmes y que la anulación solo tenga efectos a partir de una fecha incluso posterior a la de la Sentencia ${ }^{28}$.

\section{SU TRATAMIENTO EN EL DERECHO ITALIANO}

En Italia se distingue entre vicios de legitimidad (vizi di legittimità) y vicios de oportunidad (vizi di opportunità o vizi di merito).

Los de legitimidad son por vulneración de normas jurídicas, diferenciándose entre vulneración de la ley (violazione di legge), exceso de poder (ecceso di potere) e incompetencia (incompetenza).

Los de oportunidad se producen por contradicción con el interés general, aunque en principio haya conformidad con las normas y son relevantes solo cuando está previsto su control judicial o administrativo, en hipótesis extremamente raras ${ }^{29}$. La verificación de la oportunidad se realiza a través de reglas de método y de experiencia como la coherencia (coerenza), la conformidad con la Lógica (logicità) y la razonabilidad (ragionevolezza) $)^{30}$.

Hay autores que consideran que solo puede hablarse de invalidez (invalidità) en el caso de los vicios de ilegitimidad, pero otros también hablan de invalidez para los vicios de inoportunidad ${ }^{31}$.

La regla general de la ilegitimidad de los actos administrativos es la anulabilidad (annullabilità) vinculada a los tres vicios tradicionales citados (exceso de poder, etc.), como recoge el art. 21 octies de la Ley 241/1990, según la modificación realizada por la ley $15 / 2005^{32}$.

28 Décision del Consejo de Estado de 9 de marzo de 2018 núm. 407516, arriba citada. La fecha de entrada en vigor de las tarifas fue el 1 de agosto de 2017 y la fecha de efectos de la décision que marca la misma para el futuro es el 1 de agosto de 2018.

29 B. G. Mattarella (2015), «Il Provedimento», en Sabino Cassese (dir.), Corso di Diritto Amministrativo, 5a edizione, Milano: Giuffrè Editore (pág. 395).

30 B. G. Mattarella (2015: 395).

31 L. Delpino y F. Del Giudice (2008), Diritto Amministrativo, XXV Edizione, Napoli: Edizioni Giuridichi Simone (pág. 446), incluyen ambos vicios dentro de la invalidez, pero destacan que Virga restringe la invalidez a los vicios de legitimidad. Y B. G. Mattarella (2015: 395) dice que el control sobre la validez del acto es, por consiguiente, esencialmente un control sobre los vicios de legitimidad no sobre las elecciones basadas en la oportunidad.

32 B. G. Mattarella (2015: 394-395). L. Delpino y F. Del Giudice (2008: 451). 
Por tanto, la nulidad (nullità) es la excepción, que opera en supuestos tasados. La Ley 241/1990 (art. 21 septies) menciona la ausencia de los elementos esenciales del acto (il diffetto degli elementi essenziali del provvedimento), como actos privados de objeto o privados de forma, cuando esta está prescrita; la ausencia absoluta de potestad por el sujeto que dicta el acto (il diffetto assoluto di atribuzione); que el acto vulnera lo sentenciado judicialmente en casos anteriores (violazzione o elusione del giudicato), y otros casos expresamente previstos por las leyes (altri casi espressamente previsti dalla legge) ${ }^{33}$.

Se destaca que usa la Ley, a partir de la reforma de 2005, el término nulidad (nullità) para los mismos supuestos calificados anteriormente como inexistencia (inesistenza) y que, aunque pueda haber cierta diferencia teórica, la misma no es relevante, en términos concretos ${ }^{34}$. Al calificarse de inexistencia, se justificaba la jurisdicción de los órganos jurisdiccionales civiles para la tutela de los derechos subjetivos lesionados por los actos administrativos ${ }^{35}$.

Y se habla de irregularidad (irregolarità) en casos de infracciones normativas que no tienen relevancia para viciar el acto, según la jurisprudencia, que es quien ha previsto esta figura, al no estar contemplada en la normativa vigente ${ }^{36}$.

Pues bien, en caso de la nulidad, se mantiene que el acto no es susceptible de producir efectos jurídicos ${ }^{37}$, lo que comporta claramente que la declaración de nulidad comporta efectos ex tunc. Se resalta que, aunque no esté expresamente prevista una anulación por la Administración pública de sus actos nulos, a diferencia de lo que ocurre en relación con la anulabilidad, cualquier sujeto puede negarse a cumplir dichos actos; la ejecución material de los mismos puede ser impedida por el juez ordinario, a solicitud de cualquiera,

33 Una explicación bastante clara de tales supuestos puede encontrarse en V. Cerulli Illeri (2014), Lineamenti del Diritto Amministrativo, 4a ed., Torino: G. Giappicheli Editore (págs. 475-477). También los recogen B. G. Mattarella (2015: 405-406) y L. Delpino y F. Del Giudice (2008: 447-450).

Entre los «otros casos expresamente previstos en las leyes» se citan los actos dictados sin cobertura financiera o la selección de personal al servicio de las administraciones públicas sin proceso selectivo, entre otros (Mattarella, 2015: 406).

34 B. G. Mattarella (2015: 405).

35 V. Cerulli Illeri (2014: 474). En cualquier caso, se sigue manteniendo que los supuestos de nulidad continúan siendo competencia del juez ordinario (Delpino y Del Giudice, 2008: 450). Si bien el art. 21 septies, párr. 2, ha atribuido exclusivamente a la jurisdicción administrativa las cuestiones atinentes a la nulidad cuando el acto vulnera lo sentenciado judicialmente en casos anteriores (violazzione o elusione del giudicato).

36 B. G. Mattarella (2015: 406).

37 L. Delpino y F. Del Giudice (2008: 449). 
incluso en sede posesoria; y la ejecución por parte de los terceros destinatarios del acto da lugar a la exigencia del restablecimiento de las situaciones anteriores al acto, salvo en los casos excepcionales destacados por la jurisprudencia ${ }^{38}$.

La anulación por anulabilidad, en el derecho administrativo, como en las demás ramas del derecho, ya sea en vía jurisdiccional, ya sea en vía administrativa, opera de modo retroactivo, destruyendo ex tunc los efectos de la actuación administrativa ${ }^{39}$. El acto anulado desaparece del ordenamiento total o parcialmente, según del tipo de ilegalidad de que se trate, con la obligación de restaurar, en la medida de lo posible, la situación anterior al acto anulado ${ }^{40}$. Si bien la sentencia puede producir también efectos sobre la acción sucesiva de la Administración, estableciendo las reglas de actuación que deben ser seguidas por la misma, ex nunc, en los actos administrativos sustitutivos de los anteriores considerados ilegítimos (son los denominados effetti conformativi) ${ }^{41}$.

Pero, al igual que, en Francia, la jurisprudencia de su Consejo de Estado ha admitido modulaciones a dicha regla general, en este caso, a partir de la Sentencia de la Sección VI, de 10 de mayo de 2011, n. $2755^{42}$.

En ella, recoge lo siguiente:

Como regla general, con base en los principios en los que se basa la justicia administrativa, la estimación de la acción de anulación conlleva la anulación con efectos ex tunc del acto que ha resultado ilegal, con la reserva de las ulteriores actuaciones de la autoridad administrativa, que puede disponer retroactivamente con un acto que tenga efectos «ahora por entonces» ('ora per allora') ${ }^{43}$. Esta regla

38 Ibid.: 450.

39 B. G. Mattarella (2015: 403); L. Delpino y F. Del Giudice (2008: 451); V. Cerulli Illeri (2008), Lineamenti del Diritto Amministrativo, Torino: G. Giappicheli Editore, que incluye dos capítulos de "tutela giurisdizionale nei rapporti di Diritto Pubblico» (págs. 558-559). E. Casetta (2015), Manuale di Diritto Amministrativo, 17a ed. (a cura di Fabrizio Fracchia), Milano: Giuffrè Editore (pág. 545).

40 V. Cerulli Illeri (2008: 559).

41 V. Cerulli Illeri (2008: 559). S. Foà (2012), Giustizia amministrativa: atipicità delle azioni ed effettività della tutela. Il nuovo diritto giurisprudenziale, Napoli: Jovene Editore (pág. 90). Agradezco a este último autor las aclaraciones personales directas que me hizo del significado de los citados effetti conformativi.

42 Asunto del Plan de caza de la región de Puglia (Piano faunistico venatorio della Regione Puglia).

43 Los efectos «ahora por entonces» ('ora per allora') consisten en la posibilidad de que, tras la anulación por el juez del acto con efectos retroactivos (ex tunc), la Administración pueda dictar nuevos actos también con efectos retroactivos, esta vez acordes con la legalidad. Agradezco de nuevo, en relación con lo anterior, las explicaciones personales directas de Sergio Foà. 
fundamental ha sido establecida desde antiguo y antiquísimo tiempo por este Consejo (como inevitable corolario del principio de la efectividad de la tutela), ya que la medida típica del Estado de Derecho - como quedó establecido con la ley fundamental de 1889, que instituyó la Sala Cuarta del Consejo Estado- no puede ser sino la de la eliminación integral de los efectos del acto lesivo para el recurrente que ha resultado desviarse del principio de legalidad (parágrafo 15.1).

Pero añade que,

[...] sin embargo, cuando su aplicación resulte incongruente y manifiestamente injusta, o en contraste con el principio de tutela judicial efectiva [...], la regla de la anulación con efectos ex tunc del acto impugnado, en función de las circunstancias, debe encontrar una excepción, ya sea con la limitación parcial de los efectos retroactivos (Sec. VI, 9 de marzo de 2011, n. 1488), ya sea con efectos ex nunc, ya sea excluyendo totalmente los efectos de la anulación y disponiendo solamente los effetti conformativit4 (parágrafo 15.2).

Y concluye diciendo que:

el juez administrativo, en la determinación de los efectos de sus resoluciones, debe guiarse por el criterio según el cual incluso las (resoluciones) más innovadoras deben tener consecuencias coherentes con el sistema (es decir, armónicas con los principios generales del Ordenamiento y en particular con el de tutela judicial efectiva) y congruentes (en tanto que basadas en los mismos principios generales, de los cuales pueda deducirse por vía interpretativa la regla jurídica concretamente enunciada) (parágrafo 16).

Se ha llegado a decir que esta sentencia ha acabado con el dogma de la necesaria retroactividad de la anulación del acto anulable, inaugurando una nueva dirección seguida por múltiples decisiones posteriores ${ }^{45}$.

Y también se ha resaltado que, aunque en esta nueva jurisprudencia se hayan invocado en términos procesales las técnicas decisorias del Tribunal de Justicia de la Unión Europea (por la alusión, como derecho de fondo, al derecho ambiental, que es de competencia concurrente de la Unión y de los Esta-

44 Se trata pues, aquí, de que la sentencia no anula los actos considerados ilegítimos, sino que lo que hace es obligar a la Administración a dictar nuevos actos sustitutivos de los anteriores, pero con efectos desde ahora (ex nunc). Sigo igualmente, en este punto, las explicaciones del libro de Sergio Foà (2012b: 90) y las directas aclaraciones que me ha hecho, personalmente.

45 F. Caringella (2016), «Brevi osservazioni sull'annullamento con effetti variabili del provvedimento amministrativo ... verso un annullamento a geometrie variabili?», $R i$ vista "De Iustitia», 2 (pág. 11). 
dos miembros y por la obligación del Tribunal Europeo de asegurar el respeto a los principios generales comunes a los derechos de los Estados miembros), lo cierto es que la misma evolución del procedimiento administrativo hubiese podido conducir a las mismas conclusiones ${ }^{46}$.

En suma, la sentencia anulatoria puede establecer efectos retroactivos (ex tunc) totales, con posibilidad de que la Administración dicte nuevos actos con efectos retroactivos sustitutivos de los anulados (ora per allora), pero esta vez conformes con la legalidad (regla general anterior al giro jurisprudencial iniciado en 2011) ${ }^{47}$. Pero también podrá acordar, según la nueva jurisprudencia, efectos anulatorios retroactivos (ex tunc) solo parciales; efectos anulatorios desde ahora en adelante (ex nunc); o efectos no anulatorios, pero consistentes en obligar a la Administración a dictar nuevos actos sustitutivos de los anteriores con efectos desde ahora (effetti confirmativi) ${ }^{48}$.

\section{LAS PREVISIONES DEL DERECHO ALEMÁN}

En el derecho alemán se establecen diversas matizaciones distinguiendo entre actos nulos de pleno derecho y los actos que se anulan por motivos de legalidad distintos de los nulos (o sea a los que consideramos nosotros como anulables).

1. Los actos nulos de pleno derecho (nichtige Verwaltungsakte) son los que incurren en los vicios enumerados en el art. 44 de la Ley de Procedimiento Administrativo vigente, de 25 de mayo de 1976 (VwVfG). En relación con

46 S. Foà (2012), «Il giudice amministrativo tra effettività della tutela e suggestioni della Corte di giustizia: ipotesi di annullamento ex nunc del provvedimento illegittimo», $\mathrm{Fe}$ deralismi.it., Rivista diritto pubblico italiano, comunitario e comparato, 10, 16/05/2012 (pág. 19). Nos dice este autor que, precisamente, en materia urbanística, la jurisprudencia administrativa había medido el alcance de sus pronunciamientos en razón de la ponderación de los intereses a tutelar, con el fin de evitar que la anulación del instrumento planificador urbanístico general determinarse un bloqueo generalizado de toda la actividad constructora municipal y había circunscrito la eficacia de tal anulación a partes impugnadas del plan o bien solo al uso específico previsto del área, permitiendo así la reviviscencia de las disposiciones precedentes o, en el caso de anulación por vicios de procedimiento, posibilitando que se dictase un nuevo acto sin los vicios procedimentales detectados.

47 Así lo recoge el parágrafo 15.1 de la Sentencia de la Sección VI, de 10 de mayo de 2011, n. 2755.

48 S. Foà (2012: 90). 
ellos, el art. 43.3 dispone que no generan ningún efecto (unwirksam) ${ }^{49}$. Por lo tanto, no pueden producir consecuencias legales desde un principio ${ }^{50}$ y su anulación produce efectos ex tunc. Y el criterio preponderante es que la protección de la confianza legítima no opera aquí ${ }^{51}$. Si bien se ha destacado su aplicación excepcional en casos de actuaciones perjudiciales, principalmente si se trata de un acto favorable, como es el caso de una autorización. Según el Tribunal Contencioso-Administrativo Federal (BVerwG), debe tomarse en consideración, en función del caso en concreto, en el marco de las posibilidades del ejercicio de la discrecionalidad (Ermessen $)^{52}$. Así se ha llegado a aplicar la excepción cuando el destinatario pertenecía a un grupo social al que no podía exigírsele el nivel de diligencia debido ${ }^{53}$.

2. Los demás actos que vulneran el ordenamiento jurídico no calificados como nulos de pleno derecho (por tanto, nuestros actos anulables), aparecen mencionados simplemente como actos antijurídicos (rechtswidrige Verwaltungsakte) $)^{54}$.

49 Se destaca que no obtienen ni eficacia interna ni externa, sino que solo existen en el caso de actos de una autoridad con apariencia de eficacia externa (H. Knack y H. G. Henneke, 2014, Verwaltungsverfahrensgesetz Kommentar, 10 Auflage, Köln: Carl Heymanns Verlag, $\$ 44$, pág. 957, marginal 48).

50 M. Sachs (2014), Paragraphe 43-53 von, Kommentar zum Verwaltungsverfahrensgesetz', herausgegeben von P. Stelkens, H.J. Bonk y M. Sachs, 8 Auflage, München: C. H. Beck (pág. 1598, marginal 222); H. Maurer (2017), Allgemeines Verwaltungsrecht. 19 Auflage, München: Verlag C. H. Beck (pág. 304).

51 M. Sachs (2014: 1598, marginal 223). Se cita aquí la Sentencia del Tribunal Contencioso-Administrativo Federal (BVerwG) de 7 de julio de 1980 (Neue Juristische Wochenschrift 1981, pág. 363).

52 H. Maurer (2017: 305), que cita la Sentencia Peep-Show, BVerwGE 84, 314.

53 Lo recoge J. García Luengo (2002: 309-310), destacando que no concurre en tal caso el carácter evidente de la nulidad. Y también se refiere a ello R. Bocanegra Sierra (2002: 187), con alusión a la Sentencia del Tribunal Contencioso-Administrativo Federal (BVerwG) de 28 de octubre de 1959 (BVerwGE 9, 251 ff.). Se trataba del supuesto de una viuda anciana que se trasladó del Berlín oriental al Berlín occidental confiando en que era legal la continuidad de su pensión, si hacía el traslado, porque así se lo habían asegurado órganos administrativos de la Administración de la Alemania Occidental. Cuando se intentó anularla por contradecir la legalidad tal traslado, acabó aplicándosele la excepción a la declaración de nulidad, en virtud del principio de confianza legítima.

54 H. J. Wolff, O. Bachof y R. Stober (2000) ,Verwaltugsrecht', Band 2. 6 Auflage. München: Verlag C. H. Beck (pág. 111, marginales 46 y 47), invocan también las expresiones actos defectuosos (mangelhafte Verwaltungsakte) o actos erróneos (fehlerhafte Verwaltungsakte). 
Y aquí se plantea la distinción entre la anulación (Aufhebung) en vía de recurso administrativo previo (der Widerspruch) de la vía administrativa (verwaltungsinterne) o de recurso contencioso-administrativo (die verwaltungsgerichtliche Klage, también calificada como Anfechtungsklage), llamados conjuntamente medios impugnatorios o recursos legales (Rechtsbehelfe), por un lado, y la anulación de oficio por la Administración basada en la invalidez originaria (Rücknahme) o en la invalidez sobrevenida (Widerruf) del acto administrativo, por otro ${ }^{55}$.

A) La anulación (Aufhebung) en vía de recurso administrativo previo (der Widerspruch) o de recurso contencioso-administrativo (die verwaltungsgerichtliche Klage, también llamada Anfechtungsklage) tiene su regulación central en el art. 113 de la Ley de Jurisdicción contencioso administrativa vigente, de 21 de enero de 1960 (Verwaltungsgerichtsordnung-VwGO).

En él simplemente se dice que:

[...] en la medida en que el acto administrativo sea antijurídico (rechtswidrig) y el recurrente sea lesionado en sus derechos, el órgano jurisdiccional anulará (hebt [...] auf) el acto administrativo y cualquier resolución del recurso administrativo previo (Widerspruchsbescheid). Si el acto administrativo ya se ha ejecutado (vollzogen), el órgano jurisdiccional, previa solicitud de parte, también podrá declarar que la Administración tendrá que revertir la ejecución

55 En Alemania se diferencia entre anulación como supraconcepto (Aufhebung), por un lado, anulación de actos ilegales desde el principio (Rücknahme, lo que ha sido traducido al castellano por algún autor como retirada, pues en francés se ha traducido como retrait), por otro, y anulación de actos válidos en un principio que después incurren en invalidez sobrevenida (Widerruf, en francés revocation), por otro. Lo explica $\mathrm{H}$. Maurer (2017: 316-317).

Recordemos que, en nuestro derecho, la anulación, tanto en vía judicial contencioso-administrativa, como en vía de recurso administrativo y lo mismo para los actos nulos de pleno como para los actos anulables, simplemente se denomina anulación. Y, para los mecanismos dirigidos a la anulación del acto impulsados por la Administración, diferenciados tanto de los recursos administrativos como de los contencioso-administrativos, nuestro legislador utiliza el término «revisión» para los actos nulos de pleno derecho, sean favorables o de gravamen y «revocación» para los actos de gravamen, sean nulos o anulables; optando por la necesidad de autoimpugnación por la Administración ante la jurisdicción contencioso-administrativa de sus propios actos anulables favorables. Y no introduce ningún matiz terminológico según afecte a invalidez inicial o a invalidez sobrevenida.

Por eso, optaremos, algunas veces, por traducir Rücknahme con el término genérico anulación y zurücknehmen como anular $\mathrm{y}$, otras veces, incluiremos la referencia a la invalidez originaria que tiene como base, matizándolo en su caso, según afecte a actos favorables o a actos de gravamen. 
y cómo debe hacerlo. Esta declaración sólo es admisible si la Administración está en condiciones de hacerlo y dicha cuestión ha sido planteada. Si el acto administrativo ha sido eliminado previamente mediante la anulación administrativa por invalidez inicial (Rücknahme) o de otro modo, el órgano jurisdiccional, previa solicitud y mediante sentencia, decidirá que el acto administrativo ha sido antijurídico, si el solicitante tiene un interés legítimo (ein berechtigtes Interesse) en esa declaración.

Sobre ello, se destaca que, si el recurso contencioso-administrativo es admisible y digno de estimación, es obligatoria la anulación del mismo y no entra en juego el principio de protección de la confianza legítima, si ha recurrido un tercero para el que el acto administrativo es desfavorable, sin perjuicio de que se exija que ese tercero cumpla con el principio de la buena $\mathrm{fe}^{56}$.

$\mathrm{Al}$ igual que también se indica que, mientras que el alcance de la anulación, en la vía contencioso-administrativa, se determina por el alcance de la ilicitud (der Umfang der Aufhebung durch den Umfang der Rechtswidrigkeit bestimmt wird), como se deriva del citado art. 113.I.1 de la Ley de Jurisdicción Contencioso-Administrativa de 1960 (VwGO), en la anulación de oficio por la Administración debida a invalidez inicial (Rücknahme) o a invalidez sobrevenida (Widerruf), la medida en que debe anularse el acto administrativo radica en gran medida en la discrecionalidad administrativa ${ }^{57}$.

Pero, como puede observarse, no precisa la citada Ley jurisdiccional de modo taxativo el alcance temporal de la resolución judicial, aunque sí que contempla claramente los posibles efectos retroactivos de la misma (ex tunc), al decir que podrá declarar que la Administración revierta la ejecución del acto anulado ${ }^{58}$. Si bien después añade que lo anterior procede «si la Administración está en condiciones de hacerlo y dicha cuestión ha sido planteada», completándolo con la previsión de que, en caso afirmativo, deberá precisar la resolución judicial el alcance de tal reversión de efectos ${ }^{59}$.

Se resalta, así, que la regla general de la anulación es con efectos ex tunc y que la anulación con efectos ex nunc solo suele darse en el caso de actos con

56 H. Maurer (2017: 371-372). En relación con la exigencia de que ese tercero cumpla con el «principio de buena fe» se citan las sentencias BVerwGE, 44 (294, 299 ff.) y 78 (85, 88 ff.).

57 H. Maurer (2017: 319).

58 Dice exactamente: «kann das Gericht [...] aussprrechen, daß [...] die Verwaltungsbehörde die Vollziehung rückgängig zu machen hat».

59 Esto se deriva de la previsión de que no solo podrá declarar que la Administración tendrá que revertir la ejecución, sino también cómo debe hacerlo: «kann das Gericht $[\ldots]$ aussprrechen, daß und wie $[\ldots] »$. 
efectos duraderos, en el marco de la anulación de oficio ${ }^{60}$. Si los efectos del acto ya se han producido de manera definitiva y no se pueden revertir, debe declararse al menos la ilegalidad, pero, en tales casos, generalmente se otorgará un derecho a la indemnización ${ }^{61}$.

B) Sin embargo, en la regulación de las citadas anulaciones administrativas de oficio realizadas por invalidez inicial (Rücknahme) y por invalidez sobrevenida (Widerruf), llevada a cabo en la Ley de Procedimiento Administrativo vigente, de 25 de mayo de 1976 (Verwaltungsverfahrensgesetz - VwVfG), sí que encontramos una mayor precisión normativa del alcance de la anulación de los actos incursos en antijuridicidad no determinante de nulidad de pleno derecho.

3. Con respecto a la anulación de oficio por invalidez inicial (Rücknahme) de los actos anulables (rechtswidrige Verwaltungsakte), se establece, en dicha Ley procedimental administrativa, una distinción primaria entre los que denominamos actos favorables (aquellos que causan una ventaja: begünstingende Verwaltungsakte) y los que calificamos como actos desfavorables (los que imponen cargas: belastende Verwaltungsakte o nicht begünstigende Verwaltungsakte).

A) En cuanto a los actos anulables favorables (rechtswidrige begünstingende Verwaltungsakte), se ha asumido por la Ley el cambio jurisprudencial producido hacia la mitad de los años cincuenta del siglo $\mathrm{XX}^{62}$ y se diferencia así, a su vez, entre los casos en los que incida el principio de confianza legítima (Vertrauensschutz Prinzip) y aquellos en que no necesariamente concurra dicha confianza (que es la que se considera la regla general).

a) En los casos afectados por la regla general, que no se exige que concurra necesariamente el principio de confianza legitima, rige el art. 48.1 primer inciso, que dice que «un acto administrativo antijurídico, incluso después de que se ha convertido en inimpugnable (unanfechtbar), puede ser anulado (darf zurückgenommen werden) total o parcialmente, con efectos para el futuro o para el pasado" (mit Wirkung für die Zukunft oder für die Vergangenheit); por lo tanto con efectos temporales ex nunc, ex tunc e incluso iniciados en el futur ${ }^{63}$.

60 H. J. Wolff, O. Bachof y R. Stober (2000: 116, marginal 63).

61 H. J. Wolff, O. Bachof y R. Stober (2000: 116, marginal 58).

62 Hasta mediados de la década de los años cincuenta del siglo XX, el criterio aplicado en la jurisprudencia fue el de prevalencia del principio de legalidad de las administraciones públicas (die Gesetzmässigkeit der Verwaltung) y su anulación en cualquier momento mediante la anulación propia de los actos inválidos desde un principio (Rücknahme). Así lo relata H. Maurer (2017: 325).

63 El ejemplo que se señala es el de un arrendatario que, tras obtener un subsidio de vivienda el 1 de febrero del año de referencia, alquila a continuación, desde el 1 de 
Dicha previsión es considerada como una cláusula de reconocimiento de discrecionalidad administrativa en dicho ámbito ${ }^{64}$. Pero, como veremos en los párrafos sucesivos, lo cierto es que está plagado de elementos reglados expresados como conceptos jurídicos indeterminados, que reducen sobre manera la discrecionalidad ${ }^{65}$.

b) En el caso de la incidencia necesaria de la confianza legítima, se distingue a su vez entre:

$\alpha$ ) Actos de entrega de suma de dinero (por una única vez o de forma periódica) o de una prestación en especie susceptible de ser dividida o que constituyan una condición para tales prestaciones ${ }^{66}$, en los que surge una distinción ulterior basada en que concurra alguno de los tres supuestos del art. 48.2, tercer inciso, números 12 y 3, o no ${ }^{67}$.

marzo hasta finales de año, una vivienda de precio superior a la que tenía anteriormente y que financia con el nuevo subsidio de vivienda obtenido. Sin embargo, la Administración anula dicho acto por ilegalidad, el 1 de junio, y se plantea entonces si los efectos de la anulación deberían ser, en caso de concurrencia de confianza legítima, no ex nunc (desde el 1 de junio), sino desde el 1 de enero del ańo siguiente, para no afectar negativamente al alquiler de vivienda realizada, vigente hasta el 31 de diciembre del año en curso (Maurer, 2017: 335-336).

64 H. Maurer (2017: 328).

65 Así, la concurrencia de los tres supuestos enumerados en el art. 48.2, inciso tercero, números 1, 2 y 3 (incidencia de engaño malicioso, amenaza, cohecho; obtención del acto con suministro de información incorrecta o incompleta de los aspectos esenciales; y conocimiento de la ilegalidad del acto o negligencia en relación con lo anterior); la propia concurrencia de los requisitos para considerar que existe confianza legítima establecidos por la legislación y la jurisprudencia; y la previsión normativa prescriptiva de que, como regla general, se considerará la confianza legítima como digna de protección (si se cumplen sus requisitos — claro está-), por lo que el órgano competente para la anulación tendrá que justificar con la correspondiente motivación, en el caso de esos actos administrativos que proporcionan prestaciones al interesado distintos de los tres supuestos enumerados en el artículo 48.2, inciso tercero, por qué no concurre la confianza legítima o por qué el interés general exige la anulación.

66 «Ein [...] Verwaltungsakt, der eine einmalige oder laufende Geldleistung oder teilbare Sachleistung gewährt oder hierfür Voraussetzung ist». Estos son los términos exactos del art. 48.2 de la Ley.

67 Las leyes alemanas utilizan las divisiones siguientes que nos pueden generar cierta confusión: parágrafo (Paragraph, S), equivalente a nuestro artículo; apartado (Absatz); inciso o frase (Satz); y número (Nummer, Nr.). Así, en el artículo 48 (encabezado con el signo $\$$ ) se alude, en su apartado 4, al supuesto del Absatz 2 Satz 3 Nr. 1. De las explicaciones doctrinales (Maurer, 2017: 333-334), deducimos que, en tal caso, al aludir 
- Si no concurre alguno de esos tres supuestos, que es el propio de la confianza legítima, el resultado previsto es la no anulación de oficio por invalidez inicial (Nichtrücknahme) ${ }^{68} \mathrm{y}$ por lo tanto la conservación del acto.

- Si concurre alguno de tales casos (lo que hace que en realidad no pueda considerarse que incide la confianza legítima ${ }^{69}$ ), entonces la consecuencia contemplada como regla general es la anulación de oficio por invalidez inicial con efectos ex tunc (ex tunc-Rücknahme ${ }^{70}$. Dichos supuestos son: 1) si ha obtenido el acto administrativo por engaño malicioso, amenaza o cohecho; 2) si ha obtenido el acto administrativo por medio de información incorrecta o incompleta en los aspectos esenciales; y 3) si conocía la ilegalidad del acto administrativo o no la conocía como resultado de una negligencia grave.

$\beta)$ Otros actos favorables distintos de los de entrega de una suma de dinero, etc. (o sea de los indicados en nuestra letra $\alpha)^{71}$, en cuyo caso se contempla la anulación con indemnización (Rücknahme gegen Entschädigung).

B) En cuanto a los actos anulables desfavorables (rechtswidrige belastende Verwaltungsakte), rige la cláusula general del art. 48.1, primer inciso, que, como hemos visto, es la considerada como de discrecionalidad

a la frase (Satz), se está refiriendo al tercer inciso del art. 48.2, después del segundo punto y seguido, que incluye los tres apartados que a continuación se enumeran con tres números arábigos, sin estar incluidos en paréntesis.

Dice concretamente el art. 48.2, primer inciso, que si concurre confianza legítima y es digna de protección, teniendo en cuenta el interés general en la anulación, no se anulará: «Ein rechtswidriger Verwaltungsakt [...] darf nicht zurückgenommen werden, soweit der Begünstigte auf den Bestand des Verwaltungsaktes vertraut hat und sein Vertrauen unter Abwägung mit dem öffentlichen Interesse an einer Rücknahme schutzwürdig ist».

69 Como nos indica H. Maurer (2017: 333-334), la jurisprudencia del Tribunal Contencioso Administrativo Federal Alemán había venido considerando que la protección de la confianza debía ser rechazada cuando la ilegalidad del acto administrativo podía ser considerada imputable al propio afectado por el acto (BVerwGE 74, 357 y 364; 78, 139 y 142 y ss.) o incluso imputable conjuntamente a dicho afectado y a la Administración (BVerwGE 74, 357 y 364).

70 Art. 48.2, inciso cuarto (el que va después de los tres puntos del inciso tercero).

71 H. Maurer (2017: 329) se refiere a ellos como «alle übrigen Verwaltungsakte» («todos los demás actos administrativos»). 
administrativa en este ámbito. Si bien se destaca, en este caso, que han de tenerse en cuenta los criterios establecidos en el art. 51 de la Ley para modular el resultado. En dicho precepto se incluyen los supuestos de que la situación fáctica y jurídica haya cambiado con posterioridad a favor de la persona interesada, que existan pruebas que habrían provocado una decisión más favorable para la persona interesada o que concurran razones de nuestro recurso extraordinario de revisión (Wiederanfnahme) previstas en el art. 580 del Código de Procedimiento Civil (ZPO) ${ }^{72}$.

Por ello, se señala que el resultado puede llegar a ser aquí la anulación de oficio por invalidez inicial (Rücknahme) del acto (en función de la gravedad del vicio de legalidad concurrente; del prejuicio ocasionado al interesado; y el efecto para la colectividad) o la subsistencia del acto, pero con prohibición de su ejecución, lo que equivale a una anulación con efectos ex nunc (ex nuncRücknahme $)^{73}$.

4. En cuanto a la anulación de oficio por la Administración por invalidez sobrevenida (Widerruf) ${ }^{74}$, también se distingue inicialmente entre los actos favorables y actos desfavorables.

A) Respecto de los actos favorables (begünstingende Verwaltungsakte), se destaca que la protección de la confianza legítima ocupa una posición todavía más relevante que en el caso de la invalidez originaria, porque no entra en conflicto con el principio de legalidad, cuando se produce la invalidez sobrevenida, sino que actúa de forma conjunta a este ${ }^{75}$.

a) Solo es posible la anulación de oficio por invalidez sobrevenida (Widerruf) en los supuestos del art. 49.2 (presencia de una reserva de anulación de oficio por invalidez sobrevenida - Widerruf-, etc. $)^{76} \mathrm{y}$

72 La traducción literal de Wiederaufnahme es nueva admisión, pero un examen de los apartados del art. 580 del Código de Procedimiento Civil (ZPO) nos muestra que se incluyen, en el mismo, motivos semejantes a los propios de nuestros recursos extraordinarios de revisión tanto en vía administrativa como en vía contencioso-administrativa.

73 H. Maurer (2017: 356).

74 Traducido al francés como revocation, y al español, por algunos autores, como revocación, aunque nosotros seguiremos utilizando el sintagma «anulación administrativa por invalidez sobrevenida».

75 El ejemplo que se pone (Maurer, 2017: 347) es el de la licencia de obra otorgada legalmente pero que, antes de ejecutarse o terminarse de ejecutar, incurre en ilegalidad sobrevenida porque la modificación del Plan de Urbanismo ha cambiado las condiciones de edificación tenidas en cuenta en el momento de otorgarse la licencia.

76 1) Presencia de una reserva de anulación de oficio por invalidez sobrevenida (Widerruf) en el acto o que la misma esté permitida en la norma; 2) si el acto está sometido a 
del art. 49.3 de la Ley (incumplimiento del fin de la subvención o de la condición impuesta a la misma ${ }^{77}$, no fuera de tales supuestos ${ }^{78}$. Y, en los casos del art. 49.2, la regla general es la de efectos ex nunc ${ }^{79}$, mientras que, en el supuesto de los incumplimientos relativos a las subvenciones, ya citados, del art. 49.3, se destaca que la anulación de oficio por invalidez sobrevenida (Widerruf) tendrá entonces efectos ex tunc ${ }^{80}$.

b) Ahora bien, si incide la confianza legítima en los tres últimos casos del art. 49.2 (modificación de la situación de hecho o de la norma jurídica sobre las cuales se apoya el acto administrativo y que el interés público peligrase sin la anulación de oficio por invalidez sobrevenida - Widerruf - o que la anulación por invalidez sobrevenida - Widerruf - sirva para evitar o prevenir serias desventajas para el interés común), se establece una anulación de oficio por invalidez sobrevenida (Widerruf) ex nunc con indemnización ${ }^{81}$.

B) Respecto de los actos desfavorables (nicht begünstigende Verwaltungsakte), se invoca a favor de la obligación de proceder a la anulación por invalidez sobrevenida (Widerruf) el criterio del art. 51.1 de la ley: que la situación fác-

una condición y la misma no es cumplida o no lo es dentro de plazo; 3) modificación de la situación de hecho sobre la cual se apoya el acto administrativo que permitiría a la Administración no dictar el acto y que el interés público peligrase sin la anulación de oficio por invalidez sobrevenida (Widerruf); 4) modificación de la norma jurídica en la cual se apoya el acto administrativo que permitiría a la Administración no dictar el acto y que el interés público peligrase sin la anulación de oficio por invalidez sobrevenida (Widerruf); y 5) si la anulación de oficio por invalidez sobrevenida (Widerruf) sirve para evitar o prevenir serias desventajas para el interés común.

77 Un acto administrativo legal que haya otorgado una prestación monetaria de una sola vez o periódica o que haya otorgado un pago divisible en especie, para satisfacer un fin particular, o que constituya requisito para tales prestaciones puede incluso después de que se ha convertido en inimpugnable, ser anulado de oficio por invalidez sobrevenida (Widerruf), en su totalidad o en parte, con efectos retroactivos: 1) si la prestación no se utiliza para el fin previsto en el acto administrativo, inmediatamente después de su provisión o deja de serlo con posterioridad; o 2) si el acto administrativo está sometido a una condición y el beneficiario no la cumple o no lo hace dentro de plazo.

78 Dice H. Maurer que solo se permite si existe uno de esos motivos especiales (2017: 347).

79 Dice el art. 49.4 que: «El acto administrativo anulado por invalidez sobrevenida (Widerruf) se volverá ineficaz a partir de la vigencia de la anulación de oficio por invalidez sobrevenida (Widerruf), a menos que la autoridad determine otro momento (anderen Zeitpunkt)».

80 H. Maurer (2017: 347-348).

81 Art. 49.6 de la Ley procedimental administrativa. 
tica y jurídica haya cambiado con posterioridad a favor de la persona intere$\operatorname{sada}^{82}$.

Y en contra de la anulación de oficio por invalidez sobrevenida (Widerruf) se contemplan expresamente por la Ley (art. 49.1, segundo inciso), como criterios reglados, dos supuestos: a) que un acto administrativo con el mismo contenido tenga que ser obligatoriamente adoptado de nuevo ${ }^{83}$; y b) que por otras razones sea inadmisible la anulación de oficio por invalidez sobrevenida —Widerruf - (como, p. ej., por el precedente administrativo, por aplicación de principios generales del derecho; por la especialidad del acto $[\ldots])^{84}$.

Fuera de estas situaciones en las que procede o no la anulación por invalidez sobrevenida que acabamos de citar, rige la potestad discrecional para optar o no (utiliza la expresión "podrá») por ella, contemplada en el art. 49.1 de la ley ${ }^{85}$, con previsión de efectos ex nunc y carácter total o parcial ${ }^{86}$.

Se ha afirmado que tal discrecionalidad puede reducirse a cero (auf Null reduziert) precisamente en casos como el primero de los citados (o sea, aquel en el que las circunstancias fácticas o jurídicas han cambiado y que, por ello, el acto administrativo ya no se debe dictar), con exigencia, entonces, de la anulación de oficio por invalidez sobrevenida (Widerruf). A lo que se ha añadido que ello es especialmente cierto cuando un acto administrativo de efectos duraderos (Dauerverwaltungsakt, que crea una relación jurídica permanente) comporta limitación de derechos fundamentales (Grundrechtseinschrankungen) y con el cambio en la situación de hecho o jurídica las condiciones para tal limitación han desaparecido ${ }^{87}$.

5. Pero junto a lo anterior, todavía se plantea el caso de la anulación de oficio por invalidez originaria (Rücknahme) o por invalidez sobrevenida (Widerruf) de los actos mixtos, también llamados de doble efecto (mit Doppelwirkung), que son favorables para una parte y desfavorables para otra. Para este supuesto, se destaca como precepto aplicable el art. 50 de la Ley Federal de Procedimiento Administrativo (VwVfG).

En tal precepto se indica que, si un acto administrativo favorable (para una parte) que ha sido impugnado por un tercero (al que se supone

82 H. Maurer (2017: 357).

83 Dice H. Maurer (2017: 357) que esto ocurre cuando un acto debe ser dictado en virtud de una competencia reglada y las condiciones para su emisión subsisten todavía.

84 H. Maurer (2017: 357).

85 Ibid.: 358.

86 Pues dice expresamente que puede ser anulado por invalidez sobrevenida total o parcialmente con efectos para el futuro (kann [...], ganz oder teilweise mit Wirkung für die Zukunft widerrufen werden).

87 M. Sachs (2014: 1821, artículo 49, marginal 26). H. Maurer (2017: 358). 
que le perjudica y por lo tanto le es desfavorable) se anula, durante el procedimiento del recurso administrativo previo o durante el proceso judicial administrativo, no se aplicarán los apartados de los arts. 48 y 49 que especifica, que son los que establecen las limitaciones a la anulación derivadas de la aplicación del principio de confianza legítima y las previsiones de indemnización.

Y se interpreta en el sentido de que lo que contempla en dicho precepto no es tanto las condiciones para la anulación del acto administrativo dentro del procedimiento del recurso administrativo previo o del recurso contencioso-administrativo, sino las condiciones para la anulación de oficio por invalidez originaria o sobrevenida fuera de aquel proceso, justo cuando todavía se está tramitando el mismo, anticipándose, sin esperar, a su resolución ${ }^{88}$, al considerar el órgano administrativo competente que el mantenimiento de la validez del acto recurrido es insostenible. Se está refiriendo, pues, a la anulación de oficio por invalidez originaria (Rücknahme) o sobrevenida (Widerruf) y no a la anulación (Aufhebung) a través de la resolución del recurso administrativo previo (Widerspruch) o del recurso contencioso-administrativo (Anfechtungsklage) en curso ${ }^{89}$.

Se destacan como requisitos para la aplicación de tal precepto los siguientes: a) que el acto administrativo haya sido impugnado, realmente, mediante la presentación de un medio impugnatorio formal (recurso administrativo previo y recurso contencioso-administrativo), sin que la mera impugnación sea suficiente; b) que el medio impugnatorio sea admisible; c) que el procedimiento de ese medio impugnatorio esté todavía tramitándose; d) que la anulación por el órgano administrativo (fuera del procedimiento del medio impugnatorio) implique una satisfacción extraprocesal respecto del medio impugnatorio (dem Rechtsbehelf abgeholfen wird), por suponer el logro del resultado previsto en el procedimiento impugnatorio; y e) que el medio impugnatorio esté fundado, de modo que el tercero haya sido lesionado en sus derechos por el acto administrativo ${ }^{90}$.

Si bien ha existido y sigue existiendo controversia sobre la necesidad de concurrencia de los anteriores requisitos en la doctrina científica y la jurisprudencia. Para un sector se considera insignificante la exigencia de la fun-

88 F. O. Kopp y U. Ramsauer (2010), Verwaltungsverfahrensgesetz, begründet von Ferdinand O. Kopp; fortgeführt von Ulrich Ramsauer, 11 Auflage, München: C. H. Beck (\$50, marginal 3).

89 F. O. Kopp y U. Ramsauer (2010: $\$$ 50, marginales 1 y 5). M. Sachs (2014: 1888, artículo 50, marginal 100). H. Maurer (2017: 373).

90 H. Maurer (2017: 373). 
damentación del medio impugnatorio ${ }^{91}$, mientras que para otro se requiere que al menos el medio impugnatorio no sea manifiestamente infundado o manifiestamente inadmisible ${ }^{92}$.

Pero, en cualquier caso, por un lado, si se produce la anulación en los procedimientos de anulación de oficio por invalidez originaria (Rücknahme) o sobrevenida (Widerruf) y la misma se impugna, el órgano jurisdiccional contencioso-administrativo deberá examinar si el órgano administrativo enjuició correctamente la fundamentación del medio impugnatorio, es decir, si, en virtud de la misma, el medio impugnatorio habría tenido éxito ${ }^{93}$. Por otro, entrará de nuevo en juego el principio de la protección de la confianza legítima, si el tercero no tiene derecho a la corrección del acto administrativo ${ }^{94}$. Y, por otro, incluso si el tercero no tiene derecho a la corrección del acto administrativo y no puede entrar en juego el principio de la protección de la confianza legítima, podrá, en su caso, el beneficiado por el acto anulado obtener indemnización por las demás normas que contemplan indemnizaciones públicas ${ }^{95}$.

6. En conclusión y resumen, puede decirse que, en los supuestos de actos nulos de pleno derecho, la regla general es la de anulación con efectos ex tunc, que solo admite excepciones muy extremas.

Para los actos anulables objeto de anulación, las previsiones normativas son muy escuetas en relación con su anulación en vía de recurso administrativo previo (Widerspruch) y de recurso contencioso-administrativo (Anfechtungsklage), pues no precisa el art. 113.I de la Ley de jurisdicción contenciosoadministrativa vigente, de 1960, de modo taxativo el alcance temporal de la resolución judicial, aunque sí que contempla claramente los posibles efectos retroactivos de la misma (ex tunc), al decir que podrá declarar que la Administración revierta la ejecución del acto anulado. Aunque, después, añade que lo anterior procede «si la Administración está en condiciones de hacerlo y dicha cuestión ha sido planteada», completándolo con la previsión de que, en caso afirmativo, deberá precisar la resolución judicial el alcance de tal reversión de efectos.

Y se destaca que, si el recurso contencioso-administrativo es admisible y digno de estimación, es obligatoria la anulación del mismo y no entra en

91 K. Obermayer (1999), Verwaltungsverfharensgesetz Kommentar, 3 Auflage, Darmstadt: Hermann Luchterhand Verlag (\$50, pág. 1006, marginal 18).

92 M. S Sachs (2014: 1887-1888, artículo 50, marginal 99). F. O. Kopp y U. Ramsauer (2010: $\$ 50$, marginal 24).

93 H. Maurer (2017: 374).

94 Ibid

95 Ibid. 
juego el principio de protección de la confianza legítima, si ha recurrido un tercero para el que el acto administrativo es desfavorable, sin perjuicio de que se exija que ese tercero cumpla con el principio de la buena fe. Como también se ha resaltado que el alcance de la anulación, en la vía contenciosoadministrativa, se determina por el alcance de la ilicitud, como ya hemos citado atrás.

Las previsiones más detalladas aparecen en la regulación de la anulación de oficio por invalidez originaria (Rücknahme) y por invalidez sobrevenida (Widerruf) de la Ley federal de procedimiento administrativo vigente.

En relación con la anulación de oficio por invalidez originaria (Rücknahme), existe una previsión expresa de efectos ex tunc para aquellos actos de entrega de suma de dinero en los que incidan alguno de los tres supuestos del art. 48.2, tercer inciso, números 12 y 3, de la Ley Federal de Procedimiento Administrativo (incidencia de engańo malicioso, amenaza, cohecho; información incorrecta o incompleta de los aspectos esenciales; y conocimiento de la antijuridicidad del acto o negligencia en relación con lo anterior). En los demás casos, según la regla general del art. 48.1, considerada como de reconocimiento de discrecionalidad administrativa, se puede llegar a la anulación ex tunc, ex nunc e incluso a una anulación con efectos temporales no retrotraídos al pasado, ni iniciados en el presente, sino iniciados en determinado futuro. Y, si concurre confianza legítima (sin incidencia de los tres supuestos del art. 48.2, tercer inciso, números 12 y 3 , que en puridad la excluyen), se contempla llegar o bien a la no anulación del acto (para actos favorables de entrega de una suma de dinero, etc.) o bien a la anulación con indemnización (para actos favorables distintos de los de entrega de una suma de dinero, etc.).

Para la anulación por invalidez sobrevenida (Widerruf), la regla general es la de efectos ex nunc, tanto si son favorables o desfavorables. Los efectos ex tunc se prevén solo para el supuesto de las subvenciones en las que se incumple el fin de la subvención o sus condiciones. Se contempla una anulación por invalidez sobrevenida (Widerruf) ex nunc con indemnización, en los tres últimos casos del art. 49.2 (modificación de la situación de hecho o de la norma jurídica sobre las cuales se apoya el acto administrativo y que el interés público peligre sin la anulación por invalidez sobrevenida - Widerruf - o que la anulación por invalidez sobrevenida - Widerruf - sirva para evitar o prevenir serias desventajas para el interés común). Y se excluye, para los actos desfavorables, la anulación, en los casos del art. 49.1, segundo inciso, citados (que un acto administrativo con el mismo contenido tenga que ser obligatoriamente adoptado de nuevo y que por otras razones sea inadmisible tal anulación por invalidez sobrevenida - Widerruff). 
En el caso de los actos mixtos, también llamados de doble efecto (mit Doppelwirkung), que han sido favorables para una parte y que han sido impugnados por un tercero (al que se supone que le perjudica y por lo tanto le es desfavorable), a través de un recurso administrativo previo o de un recurso contencioso-administrativo, que es admisible y con una fundamentación que al menos no sea manifiestamente infundada y cuya resolución todavía está pendiente, podrá acordarse la anulación propia de dichos medios impugnatorios, fuera de los mismos, anticipándose a aquella, en el seno de un procedimiento de anulación de oficio por invalidez originaria (Rücknahme) o por invalidez sobrevenida (Widerruf). Y, en tal caso, no se aplicarán las limitaciones a la anulación derivadas de la aplicación del principio de confianza legítima y las previsiones de indemnización recogidas ordinariamente para dichas anulaciones de oficio, sin perjuicio de que sí puedan aplicarse las normas generales de indemnización pública, en su caso.

\section{CONCLUSIONES: COINCIDENCIAS FINALES A PESAR DE LAS DIFERENTES TRAYECTORIAS}

Podemos comprobar con las referencias anteriores que, tanto en el derecho francés como en el derecho italiano, la regla general ha sido, desde hace mucho tiempo, que la anulación por motivos equivalentes a los de la anulabilidad española genera efectos ex tunc y, solo a partir de 2004, en Francia, y 2011 , en Italia, se ha introducido por vía jurisprudencial la necesidad de modular tales efectos en virtud de las circunstancias concurrentes y los principios generales del derecho atinentes al caso, con posibilidad de admitirse entonces efectos ex nunc, no anulación u otros efectos.

En España, mientras que, en el derecho civil, tenía la doctrina y la jurisprudencia muy claro que la regla general era la de los efectos ex tunc, una corriente doctrinal administrativa y jurisprudencial contencioso-administrativa sui generis, sin prácticamente argumentos (pues el principal fue el falso de que en derecho civil regían los efectos ex nunc cuando no era así) y sustentada casi sobre su propia inercia mítica, ha venido defendiendo los efectos ex nunc a contracorriente de la doctrina y la jurisprudencia civil espańolas y de la doctrina y jurisprudencia administrativas de Francia e Italia.

Aunque, como hemos probado, tal criterio de la jurisprudencia contencioso-administrativa española se ve superado por la multiplicidad de sentencias de la misma jurisdicción que sí aplica los efectos ex tunc, en materia de recaudación de cuotas de la Seguridad Social; adjudicaciones de plazas de funcionario con reconocimiento del mejor derecho del recurrente y efectos de 
antigüedad y económicos correlativos; anulación de resoluciones de no ampliación del servicio activo más allá de los 65 ańos; y anulación de sanciones que conllevan el cese en el ejercicio de las funciones. Por lo tanto, esta última dirección jurisprudencial española sí que se alinea con la clásica francesa e italiana.

Ahora bien, también podemos comprobar, en la comparativa de tales derechos, que la incidencia de determinados principios jurídicos, como el de confianza legítima principalmente, pero no solo él (recuérdese, en España, el de enriquecimiento sin causa o el de continuidad de los servicios públicos y, en Francia e Italia, el de tutela judicial efectiva o de efectividad de la tutela), ha determinado en los tres países la justificación de efectos ex tunc parciales, efectos ex nunc, la exclusión de anulación u otros efectos distintos de los anteriores; lo que demuestra un acercamiento clarísimo entre los mismos, una confluencia evidente, como no podía ser de otro modo, al sustentarse en una cultura jurídica común.

También es el caso de Alemania, que, rigiendo hasta la segunda mitad del siglo xx, para los actos anulables (especialmente los favorables), el criterio de prevalencia del principio de legalidad y de los efectos ex tunc (lo que muestra la coincidencia de base con Francia e Italia hasta ese momento), se mostró pionera, a partir de dicha mitad de siglo, en la aplicación del principio de confianza legítima para modular los efectos, cuando el mismo incidiese. Criterio que ha acabado contagiando a los otros tres países, por la vía intermedia del derecho comunitario (que asumió dicho principio como propio e influyó en los ordenamientos internos de los demás Estados miembros de la Unión), de modo que, hoy en día, es común a los cuatro Estados citados la modulación de los efectos de la anulación por anulabilidad, si concurre tal principio.

Aunque, como también hemos visto, en el Estado germánico, se afirman con rotundidad los efectos ex tunc en los supuestos del art. 48.2, tercer inciso, de la Ley de Procedimiento Administrativo Alemana de 1976 (incidencia de engaño malicioso, amenaza, cohecho, etc.), excluyendo cualquier modulación en tales casos.

La única diferencia que parece sobresalir entre ellos es la afirmación actual en Alemania de que, fuera de tales supuestos, la Administración tiene discrecionalidad en la fijación de efectos, que puede conducir a la declaración de efectos ex tunc, ex nunc e incluso a efectos no iniciados a partir de la anulación, sino en determinado futuro.

Discrecionalidad que nos parece menos aceptable que el criterio de Francia e Italia (también seguido en España) de primacía de la legalidad y efectos ex tunc como regla general y excepción a dicha regla por aplicación del principio de confianza legítima y demás principios, los cuales, en realidad, no 
confieren discrecionalidad a la Administración ni a los jueces, sino que actúan como conceptos jurídicos indeterminados ${ }^{96}$.

96 Así lo ha destacado R. Dworkin, con referencia a los denominados principios en sentido estricto (1978), Taking rights seriously. Second impression (corrected with appendix and reply to critics), London: Duckworth (especialmente, págs. 31 y 69); (1984), Los derechos en serio, traducción española de Marta Guastavino de la edición de 1977 de Taking rights seriously, Barcelona: Ariel. Contiene un prólogo, titulado «Ensayo sobre Dworkin", de Alberto Casamiglia (págs. 83-94, especialmente págs. 84 y 131). Antes, se pronunció en igual sentido E. Betti (1948-1975), Interpretación de la Ley y de los actos jurídicos, Madrid: Ed. Revista de Derecho Privado (EDERSA). Es la traducción de J. L. de los Mozos de la 2a edición italiana de 1971 Interpretazione della legge e degli atti giuridici (Teoria generale e dogmatica), ed. revisada y ampliada por Giuliano Grifò, Milano: Giuffrè Editore, 1975. En realidad, procede de 1948, como se indica en el prólogo del traductor (pág. 296); (1955-1990), Teoria Generale della Interpretazione. Milano: Giuffrè Editore, 2 tomos, ed. corregida y ampliada por Giuliano Grifò, Milano, 1990, que, en realidad procede de 1955, como, en sus notas introductorias, se indica (pág. 861).

J. Leguina Villa (1987), «Principios Generales del Derecho y Constitución», Revista de Administración Pública, 114 (pág. 15), destacó tres sentencias del TC que entendieron que los principios jurídicos estaban formulados como conceptos jurídicos indeterminados (SSTC 4/1981, 62/1982 y 108/1986).

Y lo mismo hemos defendido nosotros (2011: 161 y 281 y ss., especialmente pág. 288). 
